\title{
COMMENTS
}

\section{TAXATION OF DEFERRED COMPENSATION CONTRACTS: THE UNSETTLED PROBLEM}

\begin{abstract}
A
RECENT RULING ${ }^{1}$ by the Internal Revenue Service has declared that a nonforfeitable unfunded ${ }^{2}$ contract providing for the payment of money in the future as compensation for services will not be taxable to a cash basis taxpayer at the time the contract is made. ${ }^{3}$ The tax will not be imposed on such a taxpayer until payments are actually received by him according to the terms of the deferred compensation contract. This ruling, stating the Treasury's acquiescence in Commissioner v. Oates, expressly sanctions the use of an unfunded contract as a means of deferring income from a period of high income to one of low income. The ruling may be a trap to tax planners, however, because of the recent Tax Court decision in Frank Coroden, Sx, ${ }^{5}$ where it was held that the fair market value of an unfunded deferred payment contract was taxable at the time the contract was made.

The Revenue Ruling is best understood as the product of the Seventh Circuit's 1953 decision in Commissioner v. Oates. In that case, the cash basis taxpayer, a general agent of an insurance company, contracted with the company to provide that all commissions on renewal premiums that accrued after his retirement would be paid to him when the renewal premiums were received by the company. This compensation plan resulted in a steadily declining income to the taxpayer in his retirement years. ${ }^{6}$ In order to provide a more constant
\end{abstract}

${ }^{1}$ Rev. Rul. 60-3 1 , r96o INT. Rev. Bull. No. 5, at 17.

${ }^{2}$ An unfunded contract is one unsecured by a trust, commercial annuity, or similar arrangement. See Bergen, Income Tax Aspects of Non-Qualified Deferred Compensation Plans, N.Y.U. r6TH INST. ON FED. TAX 91 ( 1958 ).

${ }^{3}$ The Code allows the taxpayer to use the cash, accrual, or any other approved method of accounting in the calculation of income. INT. REv. CODE OF $1954, \S \S 446,45$ r. The Regulations provide: "Generally under the cash receipts and disbursements method in the computation of taxable income, all items which constituted gross income (whether in the form of cash, property or services) are to be included for the taxahle year in which actually or constructively received." Treas. Reg. § 1.446-r(c) I(i) (1959). This comment will be confined to the treatment of deferred compensation agreements under the cash receipts and disbursements method. Under the accrual method of accounting, the taxpayer "must report income when the right to receive it becomes fixed." Harbor Plywood Corp., I4 T.C. 158 (1950), aff'd, I87 F.2d 734 (9th Cir. 1951).

${ }^{4}$ I 8 T.C. 570 (1952), aff'd, 207 F.2d 7 II (7th Cir. 1953), nonacq. 1952-2 CuM. BuLL. 5 .

${ }_{32}$ T.C. No. 73 (June 30, 1959), 58 MICH. L. Rev. 480.

- Because the commissions on policy premiums were spread over a nine-year period, 
retirement income, the company drafted ${ }^{7}$ an optional amendment for the contract that provided for the payment of the commissions in equal installments over a maximum period of fifteen years following the taxpayer's retirement date. ${ }^{s}$ Prior to his retirement and, therefore, prior to the date when his right to commissions arose, the taxpayer accepted the amendment to the original contract. Following the date of his retirement; he received fixed monthly payments from the company, which he reported as taxable income. ${ }^{9}$

The Commissioner contended that the commissions credited to the taxpayer when received by the company should have been included in taxable income according to the original contract. ${ }^{10}$ The Tax Court, holding that the commissions were taxable only when actually received by the taxpayer, felt that the commissions were not constructively received ${ }^{11}$ by the taxpayer when the renewal premiums were paid to the

the agent would have received, in his first year of retirement, commissions on policies written during the past nine years. During each successive year of retirement his income would have declined. In his ninth year of retirement, he would have received commissions only on the policies written in the year preceding his retirement. This natural decrease in commissions would have been intensified by the lapse of policies due to death or nonpayment of renewal premiums.

T The Special Coramittee for the Conservation of General Agent's Estates, representing the General Agent's Association of the Northwestern Mutual Life Insurance Company, aided the company in drafting the amendment.

${ }^{8}$ After the agent estimated the percentage of policyholders who would continue to pay the premiums on their policies, he consulted a commission valuation table, prepared by the company actuary, to determine the value of his future commissions. He then selected the number of years over which he wanted the value of his future commissions spread.

- The Commissioner assessed deficiencies in each of the first three tax years of the agent's retirement. During these years the accrued commissions received by the company and credited to the agent's account were more than double the commissions actually paid to the taxpayer under the amended contract. Although the company paid interest on the accumulated commissions, the Commissioner did not attempt to include the interest credited to the agent's account in this action.

${ }^{10}$ The deficiency notice sent by the Commissioner to the taxpayer stated that "the so-called Amendment . . . to your general agent's contract, which is an authorization to the insurance company to remit to you after retirement such renewal commissions as you may be entitled to under that contract, in a certain manner, has no effect on the taxability of such income." James F. Oates, 18 T.C. 570 , 571 (1952).

11 "Income although not actually reduced to a taxpayer's possession is constructively received by him in the taxable year during which it is credited to his account or set apart for him so that he may draw upon it at any time. However, income is not constructively received if the taxpayer's control of its receipt is subject to substantial limi-

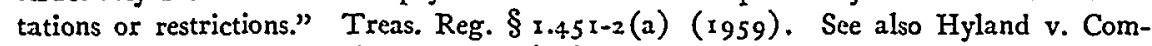
missioner, 175 F.2d 422 (2d Cir. 1949) (mere resolution of the board of directors of a corporation not sufficient to comply with the requirement that the amount be "credited" to taxpayer's account); Ross v. Comınissioner, ${ }^{6} 69$ F.2d 483 (1st Cir. 19+8) (salary 
company because he did not have an unqualified right to the commissions under the amended contract.12 The Seventh Circuit affirmed the Tax Court's decision in favor of the taxpayer.

Because the Internal Revenue Service refused to acquiesce in the Oates case, unfunded contracts have been drafted with conditions ${ }^{13} \mathrm{im}$ posed on the taxpayer's right to the deferred income in order to avoid the application of the doctrine of constructive receipt. The recent Revenue Ruling, however, clearly indicates that the Service will not apply the doctrine of constructive receipt to unfunded contracts even in the absence of any provisions in the contract that condition the taxpayer's right to the deferred compensation. ${ }^{14}$ Thus, the Service has adopted a definite policy of permitting the unfunded contract to be used to defer income from one tax period to another. The Revenue Ruling emphasizes, however, that contributions made under a deferred compensation contract to a nonforfeitable trust ${ }^{15}$ or escrow account ${ }^{16}$ will be taxable to the beneficiary at the time these contributions are made.

constructively received where corporation credited amount on its books); W.P. Henritze, 4 I B.T.A. 505 (r940) (no constructive receipt until all limitations and restrictions removed); C.E. Gullett, 3 I B.T.A. 1067 (1935) (promisor must be ready and able to pay the taxpayer amount owed him in order to utilize constructive receipt doctrine).

${ }^{12}$ See Fleming v. Commissioner, 24I' F.2d 78 (sth Cir. 1957) (amendment to an endowment insurance contract); Howard Veit, 8 T.C. 809 (1947) (amendment to an employment contract). See also J.D. Amend, i 3 T.C. i78 (1949), acq. x950-r Cum. BuLl. I (wheat farmer contracted with a grain elevator operator for immediate delivery of wheat, payment to be deferred until the next tax year).

${ }^{13}$ For example, the taxpayer must refrain from engaging in any activity in competition with his employer or must render consulting services each year. The conditions must be "real" rather than "sham." General Smelting Co., 4 T.C. 313 (r944); Carboloy Co., i 2 P-H Tax Ct. Mem. rozx (1943).

${ }^{14}$ Rev. Rul. 60-31, 1960 INT. REv. BuLl. No. 5 , sets forth five examples of deferred compensation contracts. In the first example, a corporate employer made a contract with an employee providing for services to be rendered over a five-year period. The remuneration for such services was a specified salary payable as earned and an additional amount of compensation which the employee would receive in the five-year period after the termination of his employment. In the second example, the contract provided that a certain percentage of the annual net earnings of the corporation be credited to the employee's account each year. After termination of his employment with the corporation, the employee was to receive a stated percentage of the accumulated earnings credited to his account. This payment was conditioned, however, on the employee's refraining from any competitive activity with the corporation, making himself available for consulation, and retaining unencumbered his interest in the plan.

The ruling states that the doctrine of constructive receipt will not be applied to tax the value of the contract in example one where the employee's rights are nonforfeitable, nor in example two, where the rights are forfeitable.

${ }^{15}$ Rev. Rul. 60-3I, 1960 INT. Rev. BuLl. No. 5, examples I \& 2. The ruling bases the taxation of the trust fund contributions on the statutes and regulations applicable to 
Although a cash basis taxpayer who has a right to receive benefits in the future from an unfunded contract may not, under the doctrine of constructive receipt, realize income at the time the contract is made, he might be said to realize income on the contract by applying the cash equivalent doctrine. ${ }^{17}$ For example, negotiable note received by a cash basis taxpayer in payment of an obligation is the equivalent of cash. ${ }^{18}$ The taxpayer realizes income to the extent of the fair market value ${ }^{19}$ of the note when he receives it.

Realization of income through the application of the cash equivalent doctrine is not limited to situations where the taxpayer actually receives cash or a negotiable note. The doctrine has been extended to include any "economic benefit" derived by the taxpayer. For example, cancellation of his debt is considered to be of economic benefit to the taxpayer and is treated as taxable income in the year in which the debt is cancelled. ${ }^{21}$

the taxation of nonexempt trusts established through employer-employee relationships.

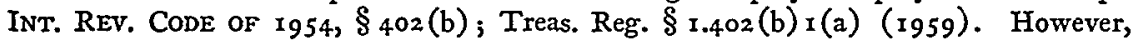
the Tax Court has applied the doctrine of constructive recepit in holding that payments made to a nonforfeitable trust were taxable to the beneficiary of the trust at the time the payments were made. George W. Drysdale, 32 T.C. No. 37 (May 22, 1959), 43 MARQ. L. REv. ${ }^{899}$ (1959). The court distinguished the Oates case as a bona fide arm'slenth transaction that had a legitimate business purpose. The Tax Court's policy of examining the circumstances and purposes involved in the establishment of the trust in the Drysdale case is utilized by the court in determining the taxability of an ordinary unfounded contract in Frank Cowden, Sr., 32 T.C. No. 73 (June 30, 1959).

${ }^{10}$ Rev. Rul. 60-31, 1960 INT. REv. BuLL. No. 5. In example 4 of this ruling, a football player contracted with a football club to play for the club for two years for a specified salary and bonus. He insisted that the bonus be paid irrevocably to an escrow agent who was instructed to distribute the money to him over a five-year period. The ruling states that the bonus would be taxed to the player when paid to the escrow agent under the cash equivalent doctrine. E. T. Sproull, I6 T.C. 244 (1951), aff'd, I94 F.2d 54I (6th Cir. 1952). However, the Revenue Ruling does not extend the cash equivalent doctrine to unfunded contracts.

17 "[I] $\mathrm{n}$ the case of one reporting income on the receipts and disbursements basis only cash or its equivalent constitutes income." John B. Atkins, 9 B.T.A. 140, 150 (1927). See also INT. REv. CODE OF I954, §6I(a).

${ }^{18}$ Pinellas Ice \& Cold Storage Co. v. Commissioner, 287 U.S. 462 (1933); Cherokee Motor Coach Co. v. Commissioner I35 F.2d 84o (6th Cir. 1943); Harry Leland Barnsley, 3 I T.C. No. 130 (March 31, 1959). See also Treas. Reg. § 1.61-2(d) (1959).

${ }^{10}$ The interest rate and the solvency of the parties liable on the note will largely determine the fair market value. Paul M. Potter, I5 P-H Tax Ct. Mem. 114 (1946).

${ }_{20} 2$ Mertens, Federal Income Taxation $\$ 11.02$ (1955). See also Commissioner v. Smith, 324 U.S. 177 (1945).

${ }^{21}$ INT. REv. CoDE OF 1954, §61(a) (12), and Treas. Reg. $\$$ I.61-12 (1959), expressly provide that the discharge of a debt is income to the debtor. See also Old Colony Trust Co. v. Commissioner, 279 U.S. 716 (1929). 
The economic benefit concept has also been used to tax funded contractual agreements. ${ }^{22}$ A deferred compensation agreement that is funded by a nonforfeitable annuity is considered to be of present economic benefit to the annuitant. ${ }^{23} \mathrm{He}$ realizes income at the time the annuity is acquired even though the annuity is unassignable and has no cash surrender value. ${ }^{24}$ The use of a trust as a funding device also results in the cestui's receiving a present economic benefit. Irrevocable contributions to the trust under a deferred compensation agreement are therefore taxable to the beneficiary when they are received by the trustee ${ }^{25}$ rather than when the trustee passes them on to the beneficiary. The Tax Court has said in a leading case that "setting up the trust conferred an economic or financial benefit"26 on the employee.

The economic benefit concept has not heretofore, however, been extended to unfunded contractual arrangements. ${ }^{27}$ The courts have held that the value of an unfunded contract to receive benefits in the future will not be taxable at the time the contract is made. The taxpayer will realize income in the taxable year in which he actually receives the payments. ${ }^{28}$ Recently, however, the Tax Court, in Frank

${ }^{22}$ The doctrine of constructive receipt has also been applied to funded contractual arrangements, such as a commercial annuity, where the taxpayer had the choice of receiving cash or a commercial annuity contract. Richard R. Deupree, I T.C. 113 (1942).

${ }^{23}$ Hubbell v. Commissioner, 150 F.2d 516 (6th Cir. 1945); Renton K. Brodie, I T.C. 275 (1942). These cases held that premium payments on a commercial annuity were taxable under the gross income provision of the Code.

${ }^{24}$ Hackett v. Commissioner, 159 F.2d 121 (1st Cir. 1946); Oberwinder v. Coinmissioner, 147 F.2d 255 (8th Cir. 1945). Cf. Ward v. Commissioner, 159 F.2d 502 (2d Cir. 1947). $(1945)$.

${ }^{25}$ J.H. McEwen, 6 T.C. 1018 (1946); David Watson Anderson, 5 T.C. 1317

${ }^{26}$ E.T. Sproull, 16 T.C. 244 (1951), aff'd, 194 F.2d 541 (6th Cir. 1952). See note 16 supra.

${ }^{27}$ In Bedell v. Commissioner, 30 F.2d 622, 624 (2d Cir. 1929), Judge Learned Hand stated: "If a company sells out its plant for a negotiable bond issue payable in the future, the profit may be determined by the present market value of the bonds. But if land or a chattel is sold, and title passes merely upon a promise to pay money at some future date, to speak of the promise as property exchanged for the title appears to us a strained use of language when calculating profits under the income tax. . . [I]t is absurd to speak of a promise to pay a sum in the future as having a 'market value,' fair or unfair. Such rights are sold, if at all, only by secking out a purchaser and higgling with him on the basis of the particular transaction." See also United States v. Christine Oil \& Gas Co., 269 Fed. 458 (1920); C. Florian Zittel, I2 B.T.A. 675 $(1928)$.

${ }^{28} \mathrm{C} . W$. Titus, 33 B.T.A. 928 (1936) (deferred payment contract for the sale of oil and gas leases held not to have a fair market value); J. Darsie LIoyd, 33 B.T.A. 903 (1936) (a noncommercial annuity contract held not to have a fair market value); 
Cowden, $S r .{ }^{29}$ held that an unfunded contract providing for future cash payments is taxable when the contract is made. In that case, the cash basis taxpayer had contracted with an oil company for the sale of oil and gas leases. The contract provided for the payment of a bonus in each of the two years following the date of the contract. The oil company was willing and able to pay the bonus immediately, but acquiesced in the taxpayer's demand for a deferred compensation plan. Prior to the actual payment of the bonus, the taxpayer sold the contract to a local bank for cash. ${ }^{30}$ The court held that the bonus contract had a fair market value and was thus taxable as gross income in the year in which the contract was made.

The Corvden case marks a significant advance in the taxation of the value of a nonforfeitable unfunded contract, although it may conflict with the instant Revenue Ruling. The court seemed to rely on the doctrine of constructive receipt when it emphasized the fact that the oil company was willing and able to pay the bonus at the time the deferred compensation contract was made. ${ }^{31}$ If the court did rely on constructive receipt when it decided to tax the value of an unfunded contract, the case is clearly in conflict with the Revenue Ruling. ${ }^{32}$ According to the Cowden interpretation of the doctrine of constructive receipt, an unfunded contract is taxable at the time it is made if the taxpayer had the choice of receiving cash or a deferred compensation contract. However, the court's inquiry into what could have been done prior to the formation of the contract, rather than what was actually done by the terms of

Charles C. Ruprecht, I6 B.T.A. 919 (I929) (a contract held to be a mere noninterest bearing account receivable).

${ }^{20}$ Frank Cowden, Sr., 32 T.C. No. 73 (June 30, 1959).

30 "Prior to the assignments of the deferred payments, at the time it first began to deal in them in $195^{\circ}$ or $195 \mathrm{I}$, the bank obtained an opinion from its counsel that the obligations represented thereby were 'direct and bankable.' The bank had, over several years, acquired a number of other such obligations in like manner. Such transactions, however, were not considered commonplace. After such assignments, generally the bank looked solely to the credit of the oil company, and did not consider the credit or recourse of the assignor." Id. at 4 .

${ }^{31}$ "In none of those cases [cited by the taxpayer] were there findings of fact, as there are here, that the bonus payors were perfectly willing and able at the time of execution of the leases and the bonus agreements to pay such bonus in an immediate Iump-sum payment; to pay the bonus immediately in a lump sum at all times thereafter until the due dates under the agreements ...." Id. at 6 .

${ }^{32}$ The Treasury has indicated it will not use the doctrine of constructive receipt to $\operatorname{tax}$ a contract providing for deferred payments. The ruling states: "[T] cannot be administered by speculating whether the payor would have been willing to agree to an earlier payment." Rev. Rul. 60-3I, x960 INT. REv. BuL.L. No. 5, at 20. 
the contract, is an unjustified extension of the doctrine of constructive receipt.

It seems more likely that, in the Cowden case, the court relied upon the doctrine of economic benefit and extended this concept to include unfunded as well as funded contracts. The court emphasized that the contract had a fair market value that was taxable when the contract was made. ${ }^{33}$ However, the court's application of the economic benefit concept to unfunded contracts is in conflict with the Revenue Ruling, which limits the doctrine of economic benefit to funded contracts. ${ }^{34}$ Due to the present uncertainty over the taxability of the value of an unfunded contract caused by the conflict between the Cowden case and the Revenue Ruling, cautious draftsmen will no doubt continue to impose conditions ${ }^{35}$ upon the taxpayer's contractual right to payment to avoid incurring an immediate tax on the value of the contract through application of the doctrines of constructive receipt and economic benefit.

It is arguable that the doctrine of economic benefit should be employed to tax the value of a nonforfeitable unfunded contract at the time the contract is made. Those who object to this extension of the concept of economic benefit point out that a commercial annuity or trust fund, as contrasted with an unfunded contract, has a fair market value equal to the face value of the fund due to the assured solvency of the promisor. This distinction, however, does not decide the question whether the unfunded contract does have a fair market value. The absence of a fund securing a deferred compensation contract does not prevent the determination of the value of the contract ${ }^{38}$ although it may affect the contract's actual market value. Thus, in determining the fair market

ss "We are convinced from the particular facts of this case that, contrary to the facts in the cited cases, here the bonus payments were not only readily but immediately convertible to and were the equivalent of cash and for that reason had a fair market value in their face amounts." Frank Cowden, Sr., 32 T.C. No. 73, at 6 (June 30, 1959). Although the taxpayer discounted the contracts in two successive years, the Tax Court held the contracts taxable at the time the contracts were executed.

${ }^{34}$ See E.T. Sproull, 16 T.C. 244 (1951), aff'd, 194 F.2d 541 (6th Cir. 1952).

${ }^{35}$ See note ${ }_{3}$ supra. See also Willis R. Dearing, 36 B.T.A. 843 (1937), aff'd 102 F.2d 91 ( 5 th Cir. 1939) where the presence of contingencies in a deferred payment oil contract prevented the immediate taxation of the contract, although the taxpayer was on the accrual basis and the parties had previously established a fair market value for the contract.

As to the desirability of retaining contingency provisions in unfunded deferred compensation contracts despite the recent Revenue Ruling, see I 2 J. TAXATION 2 10 (Ig60).

${ }^{30}$ The Tax Court said, in describing certain land contracts, that "these contracts for deeds had a fair market value and did readily pass from hand to hand in commercial dealings." Paul Haimovitz, 25 P-H Tax Ct. Mem. 59, 73 (1956). 
value of the unfunded contract, the solvency of the promisor will be an important factor. Clearly, a deferred compensation agreement payable by a large corporation of unquestioned solvency will have a substantially higher value than will a similar contract with a smaller, less secure firm.

Another objection to taxing the value of a deferred payment contract is that the recipient of a contractual right for payment of money in the future receives nothing that can be used to pay the tax. However, the lack of either assignability or cash surrender value ${ }^{37}$ of a commercial annuity has not prevented the taxation of the economic benefit derived by the annuitant at the time of his acquisition of the deferred payment annuity.

The Code provides that income should be taxable when actually or constructively received by the cash basis taxpayer. The special tax provisions for qualified employee plans ${ }^{38}$ are an important exception to the broad statutory language. These qualified plans were enacted to encourage employers to provide private social security benefits for their employees on a nondiscriminatory basis. ${ }^{39}$ The use of the unfunded deferred compensation contract by an employer for the benefit of an executive or key employee, as approved by the instant Revenue Ruling, frustrates the legislative intention of insuring equal treatment for all employees of a business organization.

Although unfunded deferred payment contracts may promote the laudable object of providing financial security for the individuals who enter into them, the statute has not provided any special tax treatment for such arrangements. Exceptions to the rule of equitable distribution of the tax burden should be narrowly confined to those situations provided for by Congress. ${ }^{40}$ In order to implement this policy of equal tax treatment, the cash basis taxpayer should be taxed on the value of $z$ nonforfeitable unfunded contract at the time the contract is made.

${ }^{37}$ See cases cited note 24 supra.

${ }^{38}$ INT. REv. CODE of 1954, $\$$ 401-04. The Code allows a deduction to the em- ployer when he makes contributions to a qualified plan. However, the employee realizes income only when the deferred payments are actually received by him.

${ }^{30}$ See Blodgett, Deferred Compensation for Executives, N.Y.U. 6TH INST. ON FED. TAX 764,768 ( I947).

${ }^{20}$ The Code allows the spreading of income over several taxable periods in some specified situations. See INT. REv. CODE OF r954, $\$ \S 1301$ (Compensation from an Employment), ${ }_{302}$ (Income from an Invention or Artistic Work), 1303 (Income from Back Pay), I304 (Compensatory Damages for Patent Infringement). 